\title{
Biogenic gas emissions from soils measured using a new automated laboratory incubation system
}

\author{
L.M. Cárdenas*, J.M.B. Hawkins, D. Chadwick, D. Scholefield \\ Institute of Grassland and Environmental Research, North Wyke, Okehampton EX20 2SB, UK
}

Received 11 July 2002; received in revised form 6 January 2003; accepted 15 January 2003

Keywords: Denitrification; Nitrous oxide; Nitrogen; Grassland soil; Emissions

Laboratory studies of nitrous oxide $\left(\mathrm{N}_{2} \mathrm{O}\right)$ and nitrogen $\left(\mathrm{N}_{2}\right)$ emissions due to denitrification in soils normally require the use of enzymatic inhibitors such as acetylene $\left(\mathrm{C}_{2} \mathrm{H}_{2}\right)$ (Parkin et al., 1984) and oxygen $\left(\mathrm{O}_{2}\right)$ (Fazzolari et al., 1998). These may disturb other processes and $\mathrm{C}_{2} \mathrm{H}_{2}$ can serve as an additional source of carbon (Swerts et al., 1996a). Data interpretation is difficult as diffusion of the $\mathrm{C}_{2} \mathrm{H}_{2}$ gas throughout the soil core cannot be guaranteed (Smith and Arah, 1992). Studies involving direct measurement of both $\mathrm{N}_{2} \mathrm{O}$ and $\mathrm{N}_{2}$ have been limited by low $\mathrm{N}_{2}$ sensitivities (Scholefield et al., 1997a). Here we describe a new laboratory system based on the replacement of the soil atmosphere by an inert gas allowing the measurement of the evolution of both $\mathrm{N}_{2} \mathrm{O}$ and $\mathrm{N}_{2}$ (Stefanson and Greenland, 1970). In an early study, Scholefield et al. (1997a) modified the technique by using intact cores and added an irrigation assembly for fertiliser application.

Soil was collected by a cylindrical corer (143 mm diameter, $120 \mathrm{~mm}$ height) pushed into the ground to a depth of $100 \mathrm{~mm}$. The corer and soil were then placed inside a cylindrical incubation vessel to an exact fit once the base of each core had been pared level with the corer edge and vegetation trimmed off. A mixture of Helium $(\mathrm{He})+\mathrm{O}_{2}$ was passed through the soil core (via the bottom of the vessel) in order to purge (flow-through mode) the soil atmosphere, headspace and all gas lines of $\mathrm{N}_{2}$. Flow rates of $\mathrm{He}$ and $\mathrm{O}_{2}\left(>100 \mathrm{ml} \mathrm{min}^{-1}\right)$ were regulated using mass flow controllers to provide an $\mathrm{O}_{2}$ concentration of c. $20 \%$ (Scholefield et al., 1997a). The $\mathrm{He}+\mathrm{O}_{2}$ mixture was then directed to the vessel via the lid (flow-over mode) after reducing the flow rate to approximately $30 \mathrm{ml} \mathrm{min}^{-1}$ and $\mathrm{N}_{2}$

\footnotetext{
* Corresponding author. Tel.: +44-1837-883-500; fax: +44-183782139.

E-mail address: laura.cardenas@bbsrc.ac.uk (L.M. Cárdenas).
}

measured until $\mathrm{N}_{2}$ levels reached baseline. We observed that after the removal of $99.996 \%$ of the soil and vessel atmosphere, the variability of each blank varied between 30 and $38 \%$ for a flow rate of $30 \mathrm{ml} \mathrm{min}^{-1}$.

Effluent gases from each of the 12 vessels passed through an outlet in the lid of the incubation vessel to an actuated 16port selection valve for either analysis or venting to the atmosphere. After replacement of the atmosphere within the soil cores, amendments were added via a secondary vessel fitted to the centre of each lid after being flushed with $\mathrm{He}$ (to avoid any atmospheric $\mathrm{N}_{2}$ contamination). The amendment vessel was cylindrical (147 $\mathrm{ml}$ volume) with a funnel shaped bottom.

The effluent gas sample was split to analyse $\mathrm{N}_{2} \mathrm{O}$ and $\mathrm{N}_{2}$. Nitrous oxide was analysed by Electron Capture Detection (ECD) and separation achieved by a stainless steel packed column ( $2 \mathrm{~m}$ long, $4 \mathrm{~mm}$ bore) filled with 'Porapak Q' (80100 mesh) and using $\mathrm{N}_{2}$ as the carrier gas. The detection limit for $\mathrm{N}_{2} \mathrm{O}$ was equivalent to $2.3 \mathrm{~g} \mathrm{~N} \mathrm{ha}^{-1} \mathrm{~d}^{-1}$. Linearity of the detector was observed between 1 and 3000 ppmv. Nitrogen was quantified by He Ionisation Detection (HID) and separation achieved by a PLOT column (30 m long $0.53 \mathrm{~mm}$ i.d.), with $\mathrm{He}$ as the carrier gas. The detection limit was $9.6 \mathrm{~g} \mathrm{~N} \mathrm{ha}^{-1} \mathrm{~d}^{-1}$ and the detector was linear from 1 to 1000 ppmv $\mathrm{N}_{2}$. The new denitrification system has a series of improvements compared to the system developed by Scholefield et al. (1997a) with which the main limitation was the sensitivity to atmospheric $\mathrm{N}_{2}$. The new system shows a detection limit five times better than its precursor (Scholefield et al., 1997a) achieved not only by means of a better analytical system, but also by using better quality materials and seals.

Incubations were carried out in a $1.3 \mathrm{~m}^{3}$ temperature controlled cabinet containing the incubation chambers, 
amendment vessels and gas lines capable of operating between 3 and $30{ }^{\circ} \mathrm{C}\left( \pm 1{ }^{\circ} \mathrm{C}\right)$. Headspace temperatures inside the vessels were logged hourly.

Soil was sampled from an experimental site at the Institute of Grassland and Environmental Research, North Wyke Research Station in Devon, UK (January-June, 2001). The soil is a clayey pelostagnogley of the Hallsworth series (Claysden and Hollis, 1984), a FAO dystric gleysol (FAO, 1990). The top $10 \mathrm{~cm}$ is characterised by $36.6 \%$ clay, $47.7 \%$ silt and $13.9 \%$ fine sand and $1.8 \%$ coarse sand in the inorganic fraction. Organic carbon (C) was 5.3\% and pH 5.7 (Harrod, 1981; Armstrong and Garwood, 1991; Scholefield et al., 1997a).

The effect of the application of $\mathrm{N}$ and $\mathrm{C}$ on $\mathrm{N}_{2} \mathrm{O}$ and $\mathrm{N}_{2}$ fluxes was evaluated and the results compared to those of Scholefield et al. (1997a,b) from similar experiments. The soil cores were watered twice with $100 \mathrm{ml}$ and left to drain for $2 \mathrm{~h}$ before being placed in the incubation vessels to insure they were at maximum soil water holding capacity ( $\sim 90 \%$ water filled pore space, WFPS). Flushing with $\mathrm{He}+\mathrm{O}_{2}$ was carried out at about $200 \mathrm{ml} \mathrm{min}^{-1}$ in flow-through mode for about $16 \mathrm{~h}$ and then the flow rate was reduced to $38 \mathrm{ml} \mathrm{min}^{-1}$ with $16 \% \mathrm{O}_{2}$ in flow-over mode until background levels of $\mathrm{N}_{2}$ were achieved. Nitrate was applied as $\mathrm{KNO}_{3}$ at a rate of $50 \mathrm{~kg} \mathrm{~N}$ ha $^{-1}$ and $\mathrm{C}$ as glucose at $363 \mathrm{~kg} \mathrm{Cha}^{-1}$. The samples were kept at $15{ }^{\circ} \mathrm{C}$ throughout the experiment. Emissions of $\mathrm{N}_{2}$ and $\mathrm{N}_{2} \mathrm{O}$ were measured simultaneously. The treatments applied were $70 \mathrm{ml} \mathrm{H}_{2} \mathrm{O}$ (vessels $1-12$ ), $49.7 \mathrm{~kg} \mathrm{~N}^{-1}$ $\left(\mathrm{KNO}_{3}\right)$ (vessels 5-12) and $363 \mathrm{~kg} \mathrm{Cha}^{-1}$ (glucose) (vessels 9-12).

Extra soil cores were analysed (square cores of $5 \mathrm{~cm} \times 5 \mathrm{~cm}$ and $10 \mathrm{~cm}$ depth) for mineral $\mathrm{N}$ as nitrate $\left(\mathrm{NO}_{3}^{-}\right)$and ammonium $\left(\mathrm{NH}_{4}^{+}\right)$before incubation. After incubation, subsamples were extracted from the cylindrical cores for similar analysis. The analysis was carried out after extraction with $2 \mathrm{M} \mathrm{KCl}$ by means of a segmented flow analyser using a colorimetric technique (Kamphake et al.,
1967; Searle, 1984). Total C and N in the soil were analysed using a TCD Carlo Erba instrument. Soil moisture was determined by gravimetric analysis after drying at $100{ }^{\circ} \mathrm{C}$ before and after incubation.

Results showed that no $\mathrm{N}_{2} \mathrm{O}$ or $\mathrm{N}_{2}$ was emitted in the water only treatment. This could be the result of denitrification occurring during the pre-incubation and flushing of the soil cores, causing exhaustion of the original $\mathrm{NO}_{3}^{-}$content in the soil. Nitrous oxide was observed in the $\mathrm{NO}_{3}^{-}$only treatment with an average maximum for four vessels of $2.7 \pm 1.23 \mathrm{~kg} \mathrm{~N}^{-1} \mathrm{~d}^{-1}, 26 \mathrm{~h}$ after amendment application (Fig. 1). Nitrous oxide emissions decreased slowly for the remainder of the experiment. The cumulative emission (calculated from the area under the curve) during the 5 days of the experiment was $8.25 \mathrm{~kg} \mathrm{~N}^{-1}(16.6 \%$ of the added $\mathrm{N}$ ) and the coefficient of variation was $40 \%$. No $\mathrm{N}_{2}$ evolution was observed in the $\mathrm{NO}_{3}^{-}$only treatment unlike the results of Scholefield et al. (1997b).

The $\mathrm{N}_{2} \mathrm{O}$ fluxes measured from the $\mathrm{NO}_{3}^{-}+$glucose treatment (Fig. 1) gave a maximum rate for three vessels of $9.8 \pm 2.43 \mathrm{~kg} \mathrm{~N} \mathrm{ha}^{-1} \mathrm{~d}^{-1}, 33.2 \mathrm{~h}$ after the application of the amendment. Calculation of the area under the curve gave a total of $25.0 \mathrm{~kg} \mathrm{~N}^{-1}$ during the 5 days of the experiment (50.4\% of the total $\mathrm{N}$ added) with a coefficient of variation of $37 \%$.

Statistical analysis of the fluxes illustrated in Fig. 1 is not simple, as different treatments produce varied temporal responses. We therefore compared the rates of increase and decrease of the fluxes. A 2-pool model was applied to fit a mathematical function to the experimental data (Dhanoa et al., 1985; Gill et al., 1985). The model calculates the rate of increase, $k_{2}$, and rate of decrease, $k_{1}$, of the fluxes after the application of the amendment, the lag time TT, which is the time it takes for the system to respond to the amendment application, and the mean retention time, MRT, which is the mean of the total time it takes for the process to occur. The inputs required by the model are the date and fluxes in $\mathrm{kg}$ $\mathrm{N} \mathrm{ha}{ }^{-1} \mathrm{~d}^{-1}$. The model reproduced the data for the $\mathrm{NO}_{3}^{-}$

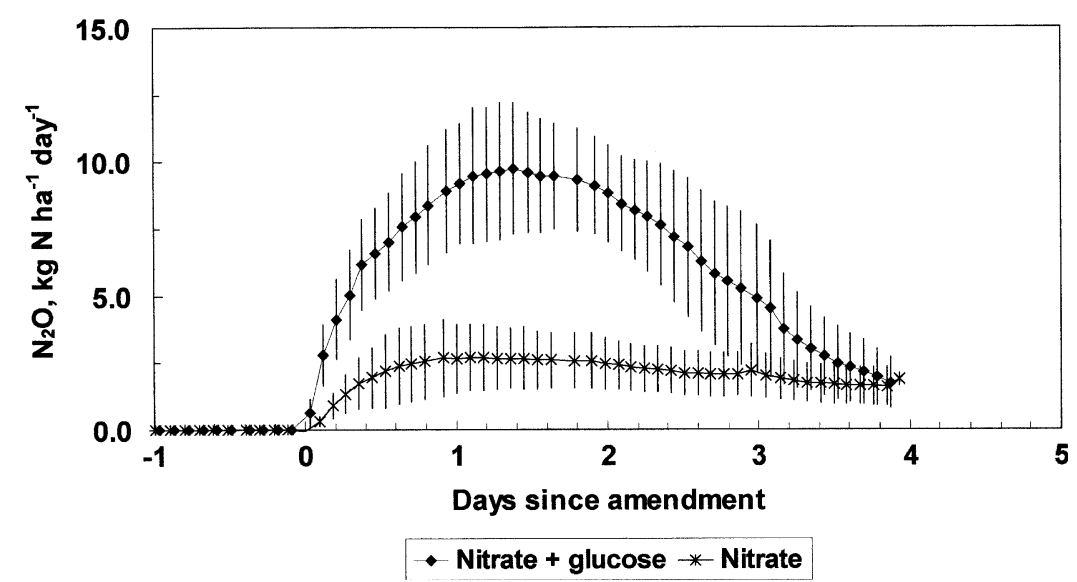

Fig. 1. $\mathrm{N}_{2} \mathrm{O}$ fluxes from the $\mathrm{NO}_{3}^{-}$only and $\mathrm{NO}_{3}^{-}+$glucose treatments (each data point is an average of four vessels for $\mathrm{NO}_{3}^{-}$only and three vessels for $\mathrm{NO}_{3}^{-}$and glucose treatments, the vertical bars correspond to the standard deviation of these averages). Day 0 corresponds to the date and time of the application of the amendment. 


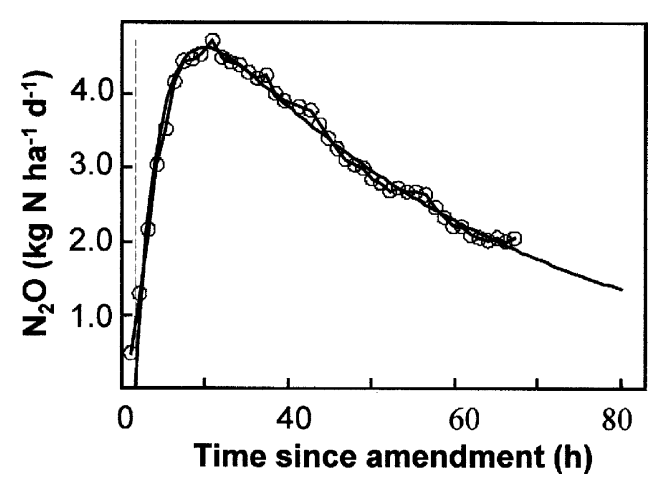

Fig. 2. Application of a 2-pool model to the $\mathrm{N}_{2} \mathrm{O}$ fluxes from one vessel. Day 0 corresponds to the date and time of the application of the amendment. The circles correspond to experimental data, the line is the modelled results. The corresponding equation for the model is: $Y=B \mathrm{e}^{-k_{1}(X-\mathrm{TT})}+$ $C \mathrm{e}^{-k_{2}(X-\mathrm{TT})}$, where rate constants $k_{1}=-0.013 / h, k_{2}=-0.1683 / h$ and lag TT $=3.2 h . B$ and $C$ are scaling constants.

Table 1

Parameters obtained from the 2-pool model.

\begin{tabular}{llllrr}
\hline Vessel & Treatment & $k_{1}$ & $k_{2}$ & $\mathrm{TT}$ & MRT \\
\hline 5 & $\mathrm{NO}_{3}^{-}$ & -0.0077 & -0.0913 & 5.5 & 146.4 \\
6 & $\mathrm{NO}_{3}^{-}$ & -0.0130 & -0.1683 & 3.2 & 86.1 \\
7 & $\mathrm{NO}_{3}^{-}$ & -0.0167 & -0.0984 & 3.0 & 73.1 \\
8 & $\mathrm{NO}_{3}^{-}$ & -0.0021 & -0.0085 & -278 & 310.0 \\
9 & $\mathrm{NO}_{3}^{-}+$glucose & -0.0331 & -0.0672 & 4.0 & 49.0 \\
10 & $\mathrm{NO}_{3}^{-}+$glucose & -0.0512 & -0.0665 & 12.3 & 46.8 \\
11 & $\mathrm{NO}_{3}^{-}+$glucose & -0.0495 & -0.0760 & 1.7 & 35.1 \\
\hline
\end{tabular}

treatments better than for $\mathrm{NO}_{3}^{-}+$glucose treatments. Fig. 2 shows an example of the application of the model to the experimental data of the average $\mathrm{N}_{2} \mathrm{O}$ fluxes for vessel six $\left(\mathrm{NO}_{3}^{-}\right.$only).

The results were analysed using the statistical package Genstat fifth edition (Table 1). $P$ values calculated for $k_{2}$ and TT were 0.117 and 0.555 , respectively, higher than 0.05 showing that these variables were the same for both treatments $\left(\mathrm{NO}_{3}^{-}\right.$and $\mathrm{NO}_{3}^{-}+$glucose). $P$ values for $k_{1}$ and MRT were 0.007 and 0.048 , respectively, significantly different for the two treatments. The similar rates of increase and lag time for the $\mathrm{NO}_{3}^{-}$only and $\mathrm{NO}_{3}^{-}+$ glucose treatments, seem to suggest that the initiation of the processes responsible for the emissions from the soil after fertilisation, depends on the $\mathrm{N}$ added but not the $\mathrm{C}$, that is the original $\mathrm{C}$ content of the soil is sufficient to initialise the process. However, the rate of decrease in emissions and, in consequence, the mean retention time, are different for both treatments suggesting that the effect of $\mathrm{C}$ is important after the process is initialised and throughout the whole period until the effect of the application expires. The $k_{1}$ value was larger for the $\mathrm{NO}_{3}^{-}+$glucose treatment than the $\mathrm{NO}_{3}^{-}$only, in agreement with a shorter MRT for the former.

The results of the $\mathrm{N}_{2}$ fluxes observed are shown in Fig. 3. Only the $\mathrm{NO}_{3}^{-}+$glucose treatment showed emission of $\mathrm{N}_{2}$. The corresponding blanks were subtracted from each vessel in order to calculate the net flux of $\mathrm{N}_{2}$. The average maximum flux observed was $2.6 \pm 0.69 \mathrm{~kg} \mathrm{~N} \mathrm{ha}^{-1} \mathrm{~d}^{-1}$, $71 \mathrm{~h}$ after amendment application and coefficient of variation was $45 \%$. The fluxes of $\mathrm{N}_{2} \mathrm{O}$ for the $\mathrm{NO}_{3}^{-}+$ glucose treatment are also shown in Fig. 3. The total $\mathrm{N}_{2}$ produced during the period of measurements was $4.97 \mathrm{~kg}$ $\mathrm{N} \mathrm{ha}^{-1}$ or $9.95 \%$ of the total $\mathrm{N}$ added. The lag period between the appearance of $\mathrm{N}_{2} \mathrm{O}$ and $\mathrm{N}_{2}$ and especially the maxima, may be due to the removal of $\mathrm{NO}_{3}^{-}$from the soil. Nitrate has preferential acceptance for electrons compared with $\mathrm{N}_{2} \mathrm{O}$, allowing $\mathrm{N}_{2} \mathrm{O}$ to accumulate and be further reduced to $\mathrm{N}_{2}$ once $\mathrm{NO}_{3}^{-}$is depleted (Swerts et al., 1996b). Although we did not measure $\mathrm{NO}_{3}^{-}$content in the soil throughout the experiment, the observed trend for both gases suggests that this was possible. Another possible explanation is the sequential synthesis of denitrification enzymes (Firestone et al., 1980).

The timing of the $\mathrm{N}_{2} \mathrm{O}$ maxima for both, $\mathrm{NO}_{3}^{-}$and $\mathrm{NO}_{3}^{-}+$glucose treatments (26 and $33.2 \mathrm{~h}$, respectively), were in agreement with Scholefield et al. (1997a) $(30 \mathrm{~h})$.

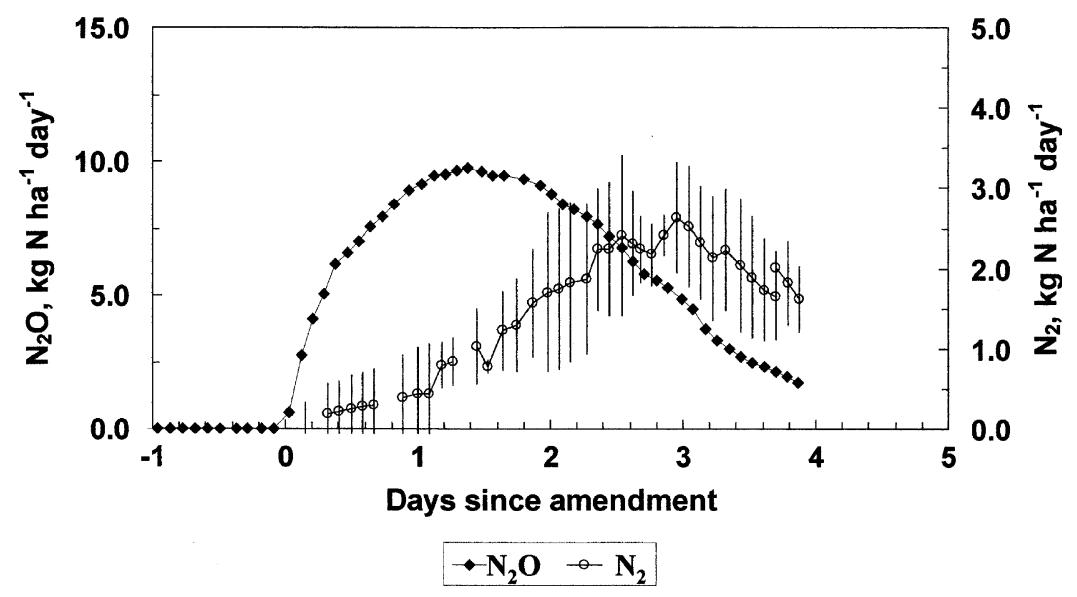

Fig. 3. Fluxes of $\mathrm{N}_{2} \mathrm{O}$ and $\mathrm{N}_{2}$ from the $\mathrm{NO}_{3}^{-}+$glucose treatment (each data point is an average of three vessels, the $\mathrm{N}_{2} \mathrm{O}$ data are the same as Fig. 1). Day 0 corresponds to the date and time of the application of the amendment. 
However, the $\mathrm{N}_{2}$ peak in Scholefield et al. (1997a) appeared $1 \mathrm{~d}$ after the $\mathrm{N}_{2} \mathrm{O}$ peak, earlier than our results at $71 \mathrm{~h}$ after applying the amendment.

The total $\mathrm{N}$ evolved during the 5 days of the experiment in the $\mathrm{NO}_{3}^{-}+$glucose treatment as $\mathrm{N}_{2} \mathrm{O}+\mathrm{N}_{2}(30 \mathrm{~kg}$ $\mathrm{N} \mathrm{ha}^{-1}$ ) accounted for $60 \%$ of the $\mathrm{N}$ applied, higher than the $50 \%$ that Scholefield et al. (1997a) could account for. We found that soil samples contained $\mathrm{NH}_{4}^{+}-\mathrm{N}$ and $\mathrm{NO}_{3}^{-}-\mathrm{N}$ after the experiment: 2.67 and $12.24 \mathrm{~kg} \mathrm{~N}^{-1}$ (respectively) for $\mathrm{NO}_{3}^{-}$only, and 3.49 and $3.94 \mathrm{~kg} \mathrm{~N}$ ha $^{-1}$ (respectively) for $\mathrm{NO}_{3}^{-}+$glucose. Taking into account all the measured $\mathrm{N}$ species we can account for a total of $23.2 \mathrm{~kg}$ $\mathrm{N} \mathrm{ha}^{-1}$ in the $\mathrm{NO}_{3}^{-}$only treatment (46\% of the $\mathrm{N}$ applied) and $37.4 \mathrm{~kg} \mathrm{~N} h a^{-1}$ (75\% of the $\mathrm{N}$ applied) in the $\mathrm{NO}_{3}^{-}+$ glucose treatment. These total values are low compared with the results of Scholefield et al. (1997a). This was mainly due to the fact that we did not find a large amount of $\mathrm{NH}_{4}^{+}-\mathrm{N}$ in the soil after the experiment in the $\mathrm{NO}_{3}^{-}+$glucose treatment whereas Scholefield et al. (1997a) found 37.4\% of the $\mathrm{N}$ applied was in the form of $\mathrm{NH}_{4}^{+}$.

The results of the soil analysis could have also been affected by the method of collection of the subcore from the sample after the experiment, since it was taken from the middle and might not have represented the whole core. Total $\mathrm{C}$ and $\mathrm{N}$ did not show a great difference with the original $\mathrm{C}$ and $\mathrm{N}$ content of the soil. Other forms of $\mathrm{N}$ not accounted for, such as biomass assimilation and $\mathrm{N}_{2}$ fixation, could have affected our balance.

Another factor that could explain some of the differences between these results and those of Scholefield et al. (1997a) is the shape and size of the core. The collection of 25 small soil cores to fit a large chamber in Scholefield et al. (1997a) was replaced by one larger circular core in the present work. It is possible that the ratio of flow rate:surface area of the core affects the proportion of $\mathrm{N}_{2} \mathrm{O}$ to $\mathrm{N}_{2}$. In the previous

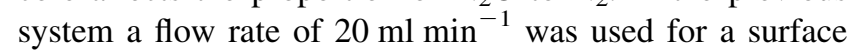
area of $506 \mathrm{~cm}^{2}$. The new system has a flow rate of $38 \mathrm{ml} \mathrm{min}^{-1}$ for a surface area of $154 \mathrm{~cm}^{2}$. This results in a 5.5 times faster flow rate relative to surface area in the new system, which could help in the transport of the gases emitted in the soil to the headspace. Further studies will help in the understanding of the effect of some of these parameters (such as flow rate) on the emissions.

\section{Acknowledgements}

The authors thank E. Jewkes, M. Butler, A. Stone, E. Williams, A. Bristow and D. Dhanoa for help during sampling, soil analysis and statistical analysis. We thank the Plymouth Marine Laboratory for loan of equipment and P. Nightingale for proof reading. Thanks to the
Biotechnology and Biological Sciences Research Council (BBSRC) for funding this project. IGER is supported by the BBSRC, Swindon, England.

\section{References}

Armstrong, A.C., Garwood, E.A., 1991. Hydrological consequences of artificial drainage of grassland. Hydrological Processes 5, 157-174.

Clayden, B., Hollis, J.M., 1984. Criteria for Differentiating Soil Series, Technical Monograph No. 17, Soil Survey of England and Wales, Harpenden.

Dhanoa, M.S., Siddons, R.C., France, J., Gale, D.L., 1985. A multicompartmental model to describe marker excretion patterns in ruminant faeces. British Journal of Nutrition 53, 663-671.

FAO, 1990. FAO-UNESCO Soil Map of the World, World Soil Resources Report 60, vol. I. UNESCO, Paris.

Fazzolari, E., Nicolardot, B., Germon, J.C., 1998. Simultaneous effects of increasing levels of glucose and oxygen partial pressures on denitrification and dissimilatory nitrate reduction to ammonium in repacked soil cores. European Journal of Soil Biology 34, 47-52.

Firestone, M.K., Firestone, R.B., Tiedje, J.M., 1980. Nitrous oxide from soil denitrification: factors controlling its biological production. Science 208, 749-751.

Gill, M., France, J., Siddons, R.C., Dhanoa, M.S., 1985. Compartmental models incorporating particle size for the estimation of digestion in the rumen. Techniques in Particle Size Analysis of Feed and Digesta in Ruminants. In: Kennedy, P.M. (Ed.), Proceedings of a Workshop held at the Banff Centre, Banff, Canada, 7-8 September 1984, Canadian Society of Animal Science Occasional Publication 1, Edmonton, Alberta, Canada: Canadian Society of Animal Science, pp.142-153.

Harrod, T.R., 1981. The Soils of North Wyke and Rowden, Soil Survey of England and Wales, Harpenden, Herts, UK.

Kamphake, L.J., Hannah, S.A., Cohen, J.M., 1967. Automated analysis for nitrate by hydrazine reduction. Water Research 1, 205-216.

Parkin, T.B., Kaspar, H.F., Sexstone, A.J., Tiedje, J.F., 1984. A gas-flow soil core method to measure field denitrification rates. Soil Biology \& Biochemistry 16, 323-330.

Scholefield, D., Hawkins, J.M.B., Jackson, S.M., 1997a. Development of a helium atmosphere soil incubation technique for direct measurement of nitrous oxide and dinitrogen fluxes during denitrification. Soil Biology \& Biochemistry 29, 1345-1352.

Scholefield, D., Hawkins, J.M.B., Jackson, S.M., 1997b. Use of a flowing helium atmosphere incubation technique to measure the effects of denitrification controls applied to intact soil cores of a clay soil. Soil Biology \& Biochemistry 29, 1337-1344.

Searle, P.L., 1984. The Berthelot or Indophenol reaction and its use in the analytical chemistry of nitrogen. Analyst 109, 549-568.

Smith, K.A., Arah, J.R.M., 1992. Measurement and modelling of nitrous oxide emissions from soils. Ecological Bulletins 42, 116-123.

Stefanson, R.C., Greenland, D.J., 1970. Measurement of nitrogen and nitrous oxide evolution from soil-plant systems using sealed growth chambers. Soil Science 109, 203-206.

Swerts, M., Merckx, R., Vlassak, K., 1996a. Denitrification, $\mathrm{N}_{2}$ fixation and fermentation during anaerobic incubation of soils amended with glucose and nitrate. Biology and Fertility of Soils 23, 229-235.

Swerts, M., Merckx, R., Vlassak, K., 1996b. Denitrification followed by $\mathrm{N}_{2}$ fixation during anaerobic incubation. Soil Biology \& Biochemistry 28, $127-129$. 